\title{
LANTAI PEMANEN ENERGI LISTRIK MENGGUNAKAN PIEZOELEKTRIK
}

\author{
M. Imbarothur Mowaviq ${ }^{1}$, Andi Junaidi ${ }^{2}$, dan Sugeng Purwanto ${ }^{3}$ \\ ${ }^{1,2,3}$ Sekolah Tinggi Teknik - PLN \\ mowaviq@sttpln.ac.id
}

\begin{abstract}
This research illustrates how piezoelectric as an electrical generator designed on the floor. Piezoelectric is a transducer that changes either from electrical energies to mechanical or from mechanical energies to electrical. By designing piezoelectric in the floor, waste energy from footsteps can be utilized. The piezoelectric generated low power by stress. To compensate for the very low power of the piezoelectric generator, it can generate more power by connecting the piezoelectrics in parallel. The piezoelectrics generate electrical power in alternating current. Therefore, in order to the battery can store the energy, the output of the piezoelectrics should be rectified by rectifier circuits. The piezoelectrics have characteristic that more stress can generate more power. To charge the cell phone size battery, the electric energy harvesting floor should get a huge number of footsteps. Accordingly, it should be assembled in public facilities like a train station.
\end{abstract}

Keywords: Piezoelectric, Electrical Generator, Floor, Low Power

\begin{abstract}
ABSTRAK
Penelitian ini menggambarkan bagaimana piezoelektrik sebagai generator listrik dirancang di lantai. Piezoelektrik adalah transduser yang mengubah energi listrik menjadi energi mekanik atau energi mekanik menjadi listrik. Dengan merancang piezoelektrik di lantai, energi limbah dari langkah kaki dapat dimanfaatkan. Piezoelektrik menghasilkan daya yang rendah akibat dari tekanan. Untuk mengkompensasi daya yang sangat rendah dari generator piezoelektrik, maka daya dapat dihasilkan lebih banyak daya dengan menghubungkan piezoelektrik secara paralel. Piezoelektrik menghasilkan daya listrik dalam arus bolak-balik. Oleh karena itu, agar baterai dapat menyimpan energi, listrik yang dihasilkan piezoelektrik harus diperbaiki oleh sirkuit penyearah. Piezoelektrik memiliki karakteristik bahwa lebih besar tekanan dapat menghasilkan daya yang lebih besar. Untuk mengisi baterai ukuran ponsel, lantai pemanenan energi listrik harus mendapatkan banyak langkah kaki. Oleh karena itu, harus dirakit di fasilitas umum seperti stasiun kereta api.
\end{abstract}

Kata kunci: Piezoelektrik, Generator Listrik, Lantai, Daya Rendah 


\section{PENDAHULUAN}

Kebutuhan energi listrik yang selalu meningkat mesti dapat dipenuhi agar tidak terjadi kelangkaan energi. Lebih lagi, pembangkitan energi listrik dari sumber daya fosil yang selama ini menjadi andalan sudah harus diminimalisasi agar tidak terjadi perusakan lingkungan yang signifikan. Oleh sebab itu, perlu diberikan solusi alternatif penghasil energi listrik baru terbarukan yang ramah lingkungan. Sumber daya energi yang ramah lingkungan tersebut bisa diperoleh dari energi yang selama ini tanpa disadari terbuang begitu saja. Salah satunya adalah energi mekanik berupa getaran yang dihasilkan akibat langkah kaki manusia. Pembangkitan energi berdaya rendah yang dihasilkan oleh getaran telah menarik perhatian secara signifikan [1].

Pemanenan energi dari getaran dapat menggunakan material piezoelektrik. Material piezoelektrik merupakan suatu material yang mampu menghasilkan listrik ketika mengalami defleksi [2]. Beberapa peneltian telah mendahului penelitian tentang pemanfaatan piezoelektrik sebagai penghasil energi. Salah satunya adalah pemanfaatan piezoelektrik yang didesain pada sepatu [3] atau pada polisi tidur dengan sistem kantilever [2]. Rumusan masalah dari penelitian ini adalah bagiaman desain lantai yang dapat menghasilkan energi listrik akibat langkah kaki manusia menggunakan piezoelektrik. Seberapa banyak dan bagaimana agar energi listrik yang dapat dihasilkan lantai dapat optimal.

\section{METODE/PERANCANGAN PENELITIAN}

\subsection{Piezoelektrik}

Piezoelektrik adalah fenomena yang ditemukan oleh Curie bersaudara pada tahun $1880 \mathrm{di}$ mana dihasilkan listrik dari kristal yang mendapat tekanan mekanis [3]. Kata piezo sendiri merupakan bahasa Yunani yang berarti tekanan [4]. Efek piezoelektrik dihasilkan dari interaksi elektromekanik linear antara bagian mekanik dan listrik yang ada di dalam Kristal [5]. Bahan piezoelektrik ketika belum terpolarisasi karena tidak ada tekanan yang diberikan (Gambar 1.a). Sementara, setelah piezoelektrik mendapatkan tekanan, piezoelektrik akan mengalami polarisasi dan menghasilkan listrik (Gambar 1.b).
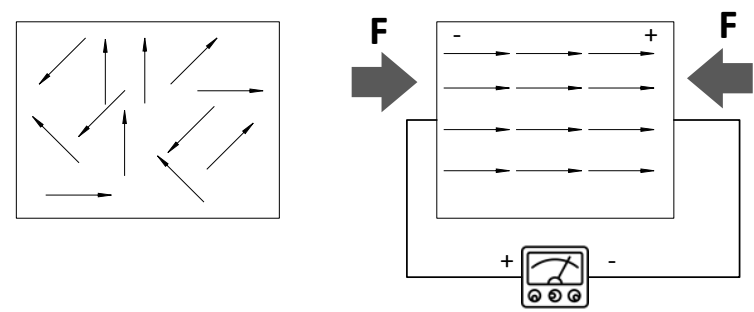

Gambar 1. Polarisasi pada Piezoelektrik (a) Tidak terpolarisasi (b) Terpolarisasi [6]

Terbangkitnya listrik pada piezoelektrik akibat adanya tekanan mekanik ini kemudian disebut dengan efek piezoelektrik [7]. Efek piezoelektrik sendiri terbagi dua, yaitu efek piezoelektrik langsung yang mengubah tekanan mekanik menjadi listrik (Gambar 2.b dan 2.c), dan efek piezoelektrik terbalik yaitu mengubah bentuk bahan piezoelektrik dengan memberikan tegangan listrik (Gambar 2.d dan 2.e) [8]. 
(a)

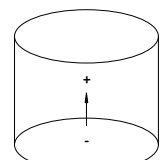

(d)

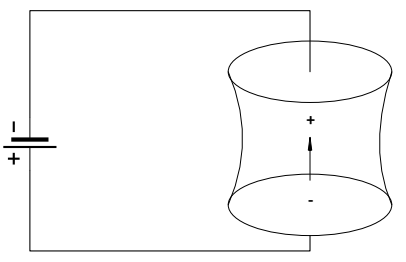

(b)

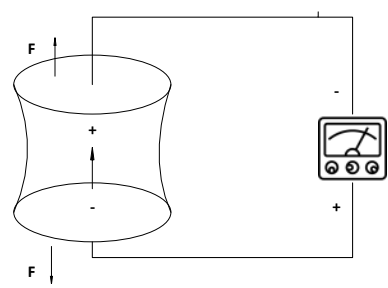

(e)

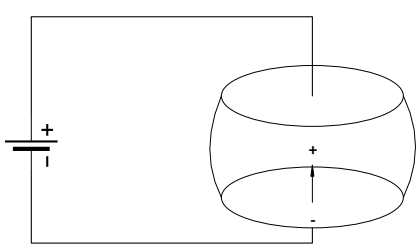

(c)

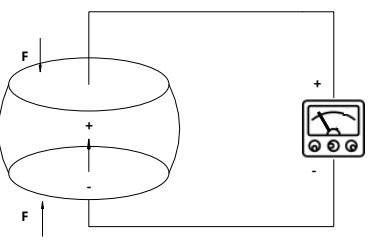

Gambar 2. Efek Piezoelektrik, (a) sebelum terjadi efek piezoelektrik, (b) dan (c) efek piezoelektrik langsung, (d) dan (e) efek piezoelektrik terbalik [4]

\subsection{Rangkaian Pembangkit Listrik Piezoelektrik}

Piezoelektrik dalam sekali tekan dan dilepaskan akan menghasilkan arus bolak-balik. Sehingga untuk mendapatkan energi yang maksimal dan dapat disimpan dalam baterai maka perlu disearahkan dengan rectifier (Gambar 3). Karena energi listrik yang dihasilkan piezoelektrik sangat kecil, energi listrik disimpan terlebih dahulu dalam baterai atau kapasitor sebelum digunakan pada beban.

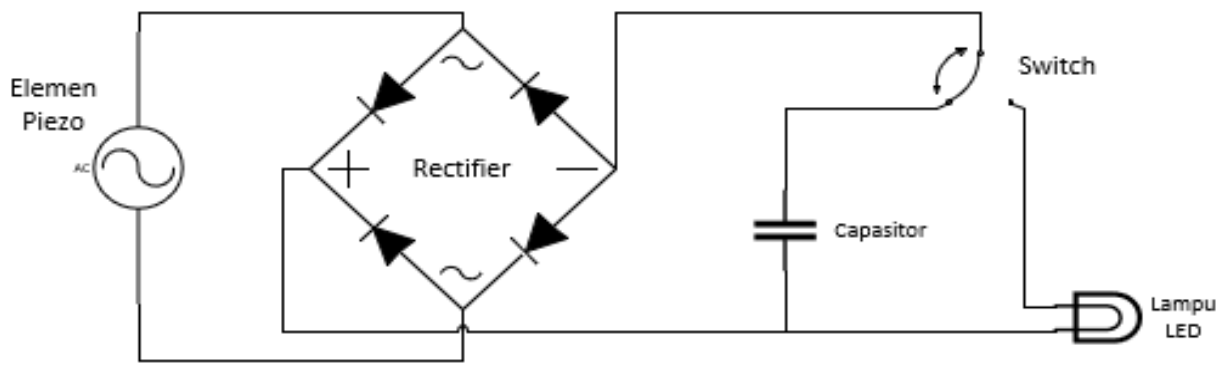

Gambar 3. Rangkaian Pembangkit Piezoelektrik [9]

Energi yang dihasilkan diketahui dengan mendapatkan nilai tegangan yang berada pada kapasitor. Adapun, besar energi yang tersimpan adalah:

$E=\frac{1}{2} C V^{2}$

Di mana $V$ adalah tegangan pada kapasitor dalam volt $(\mathrm{V}), C$ adalah kapasitansi dalam farad (F), dan $E$ merupakan energi dalam joule (J) atau ekuivalen dengan watt-sekon (W-s). Untuk menghitung jumlah energi yang tersimpan dalam kapasitor dalam sekali tekan $\left(E_{\text {tap }}\right)$, dapat diperoleh dengan mendapatkan tegangan sebelum $\left(V_{0}\right)$ dan sesudah ditekan $\left(V_{1}\right)$. Sehingga, energi dalam sekali tekan adalah hasil dari

$E_{\text {tap }}=\frac{1}{2} C\left(V_{1}^{2}-V_{0}^{2}\right)$ 


\subsection{Desain Lantai}

Piezoelektrik dapat dihubungkan secara paralel untuk meningkatkan energi yang dihasilkan. Piezoelektrik yang dirangkai paralel menghasilkan arus yang tetap dengan tegangan yang bertambah. Jumlah total tegangan yang dihasilkan pada rangkaian piezoelektrik yang terhubung paralel adalah sama dengan penjumlahan total tegangan yang dihasilkan oleh masing-masing piezoelektrik. Sementara, arus total sama dengan masing-masing piezoelektrik [10]

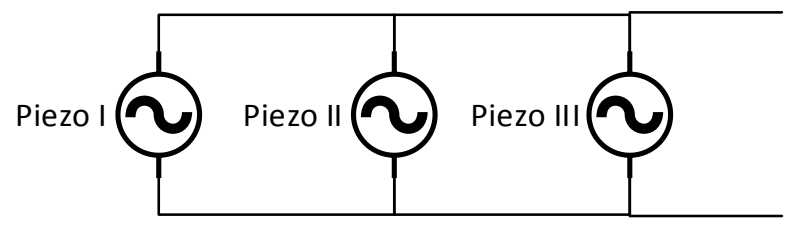

Gambar 4. Rangkaian Piezoelektrik Paralel [10]

$$
V_{\text {total }}=V_{1}+V_{2}+V_{3}
$$

$I_{\text {total }}=I_{1}=I_{2}=I_{3}$

Di mana $V_{1}, V_{2}$, dan $V_{3}$ masing-masing adalah tegangan yang dihasilkan oleh piezoelektrik I, piezoelektrik II, dan piezoelektrik III dengan $V_{\text {total }}$ tegangan yang dihasilkan oleh seluruh piezoelektrik. Sedangkan $I_{1}, I_{2}$, dan $I_{3}$ adalah arus yang dihasilkan oleh masing-masing piezoelektrik dengan $I_{\text {total }}$ adalah total arus yang dihasilkan seluruh piezoelektrik.

Desain lantai dibuat dengan memberikan benda berbahan keras seperti kayu atau akrilik. Piezoelektrik yang digunakan adalah piezoelektrik yang berbentuk lingkaran berukuran $35 \mathrm{~mm}$. Piezoelektrik yang telah dirangkai paralel kemudian dialasi dengan benda berbahan karet atau benda elastic lainnya. Bagian yang terinjak oleh kaki manusia adalah bagian atas yang keras, sehingga tekanan dapat merata di seluruh elemen piezoelektrik. Kabel penghubung kemudian dihubungkan dengan rangkaian pembangkit. Desain lantai secara keseluruhan dapat dilihat pada Gambar 4.

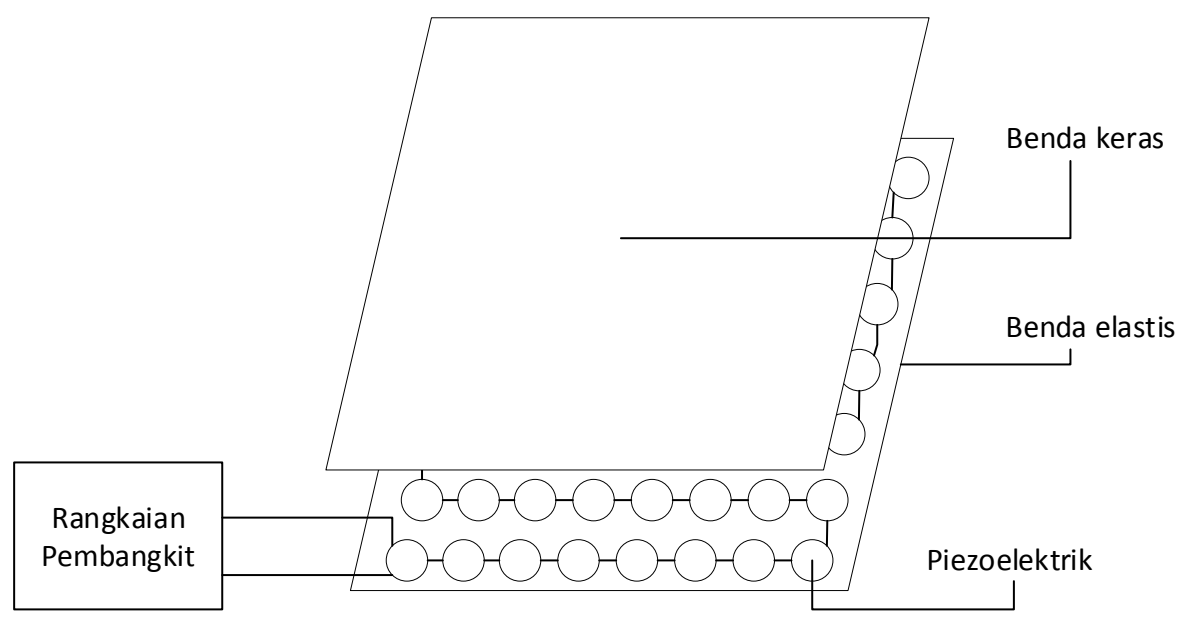

Gambar 4. Desain Lantai Pembangkit Listrik dengan Piezoelektrik 


\subsection{Pengujian dan Analisis}

Pengujian dilakukan dengan beberapa tahap, yaitu:

1. Pengujian rangkaian pembangkit piezoelektrik terhubung paralel.

Pengujian ini dilakukan dengan 9 buah yang dihubungkan paralel dengan rangkaian pembangkit. Pada pengujian ini parameter tegangan dan diukur menggunakan multimeter. Pengujian dilakukan dengan langkah orang yang memiliki tiga varisasi beban, yaitu $60 \mathrm{~kg}, 80$ $\mathrm{kg}$, dan $100 \mathrm{~kg}$.

2. Analisis Desain Lantai

Analisis desain lantai ini dilakukan dengan menghitung energi yang dihasilkan. Selain itu, analisis juga dilakukan dengan melakukan perhitungan kebutuhan jumlah piezoelektrik, jumlah langkah kaki manusia untuk mendapat energi setara dengan baterai telepon genggam berukuran $4000 \mathrm{mAh}$.

\section{HASIL DAN PEMBAHASAN}

\section{a. Pengujian Rangkaian Piezoelektrik Terhubung Paralel}

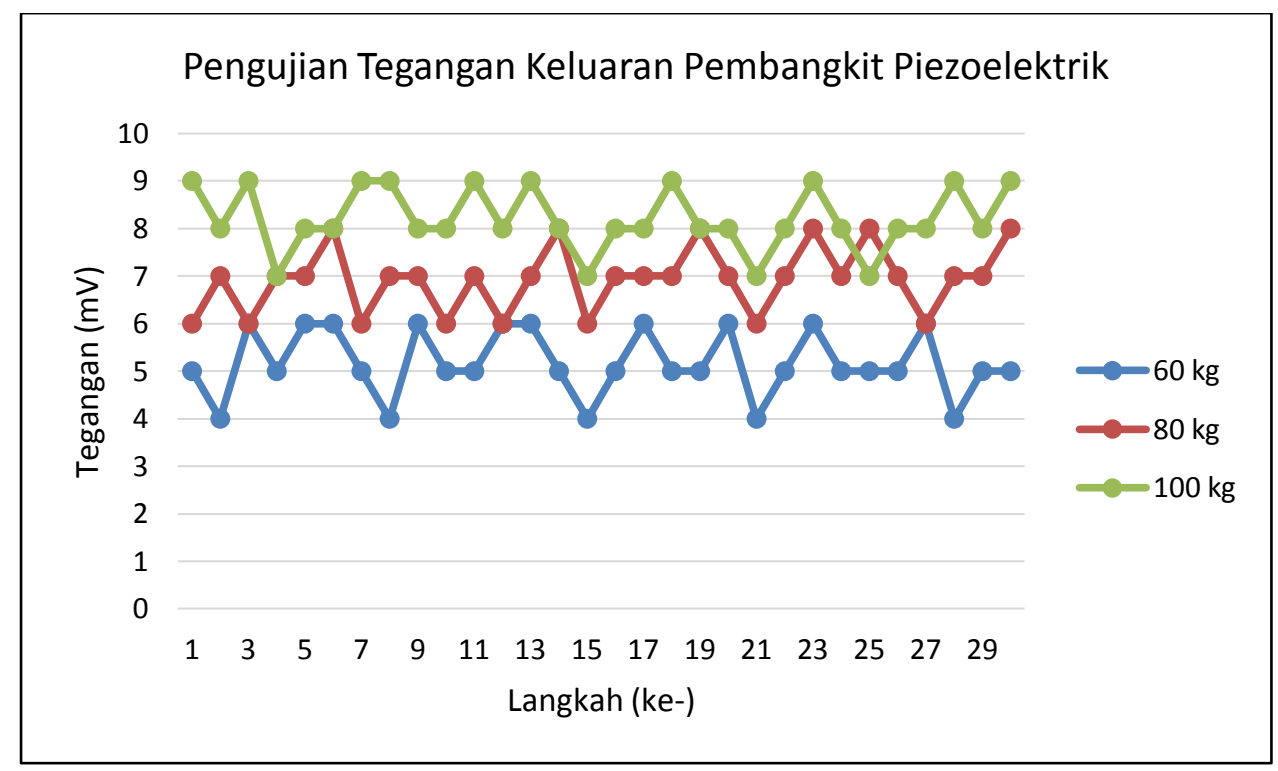

Gambar 5. Pengujian Tegangan Keluaran Pembangkit 9 Piezoelektrik Terhubung Paralel

Pada Gambar 5, garis berwarna hijau, merah, dan biru masing-masing menunjukkan tegangan keluaran akibat langkah manusia bermassa $100 \mathrm{~kg}, 80 \mathrm{~kg}, 60 \mathrm{~kg}$. Dari hasil pengujian di atas, tegangan keluaran berubah-ubah dengan batasan tertentu. Pada beban bermassa $60 \mathrm{~kg}$, tegangan yang dihasilkan berkisar antara 4-6 mV. Pada beban bermassa $80 \mathrm{~kg}$, tegangan keluaran berkisar 6$8 \mathrm{mV}$. Sedangkan pada beban bermassa $100 \mathrm{~kg}$, menghasilkan tegangan berkisar 7-9 mV.

Dari pengujian ini, juga dapat kita lihat bahwa semakin besar massa beban yang diberikan, semakin besar tegangan yang dihasilkan. Hal ini sesuai dengan prinsip dari piezoelektrik yang merubah energi mekanik, dalam hal ini tekanan yang dihasilkan dari berat tubuh manusia, menjadi energi listrik. Selain itu, dengan merangkai piezoelektrik secara paralel energi listrik yang disimpan pada kapasitor semakin besar. 


\section{b. Analisis Desain Lantai}

Jika diasumsikan massa manusia rata-rata adalah $80 \mathrm{~kg}$, maka tegangan keluaran setiap langkah manusia ada 6-8 $\mathrm{mV}$ setiap 9 buah piezoelektrik yang dirangkai paralel. Maka, dengan mengasumsikan sekali lagi bahwa jika beban sebesar $80 \mathrm{~kg}$ maka rata-rata akan menghasilkan 7 $\mathrm{mV}$ setiap 9 buah piezoelektrik. Dengan memperhatikan persamaan (1) maka dapat kita peroleh energi yang tersimpan dalam sebuah super kapasitor dengan kapasitansi $4700 \mu \mathrm{F}$ adalah

$$
\begin{gathered}
E=\frac{1}{2} \times\left(4700 \times 10^{-6} \mathrm{~F}\right) \times\left(\frac{7 \times 10^{-3} V}{9}\right)^{2} \\
E=1,421 \times 10^{-10} \mathrm{~J}
\end{gathered}
$$

Maka untuk mengisi baterai dengan kapasitas $4000 \mathrm{mAh}$ dengan tegangan $5 \mathrm{~V}$ maka energi yang dibutuhkan adalah $20 \mathrm{~W}$-h atau sama dengan 72000 joule.

Pada lantai berukuran $50 \mathrm{~cm}$ x $50 \mathrm{~cm}$ dengan piezoelektrik berukuran $35 \times 35 \mathrm{~cm}$ maka dapat dipasang 200 buah piezo elektrik. Maka sebuah lantai berukuran 50 x $50 \mathrm{~cm}$ dapat menghasilkan energi sebesar

$$
E=200 \times\left(1,421 \times 10^{-10}\right) J=2,842 \times 10^{-8} J
$$

Jumlah langkah manusia yang dibutuhkan untuk mengisi sebuah baterai telepon genggam pada lantai berukuran $50 \times 50 \mathrm{~cm}$ adalah

$$
\text { Jumlah langkah }=\frac{\text { Kapasitas Baterai }}{\text { Energi per langkah }}=\frac{72000}{2,842 \times 10^{-8}}=2,533 \times 10^{12}
$$

Dengan jumlah sebanyak itu, tempat yang memungkinkan dipasang sebuah lantai pembangkit listrik dengan menggunakan piezoelektrik adalah fasilitas publik yang sering digunakan orang seperti stasiun tanah abang yang penumpangnya mencapai 110.000 orang per hari [11].

\section{KESIMPULAN DAN SARAN}

Lantai pembangkit listrik menggunakan piezoelektrik ini merupakan penghasil energi listrik berdaya rendah. Meski berdaya rendah, pembangkit ini memiliki keunggulan karena bebas polusi dan didapat dari energi yang selama ini terbuang sia-sia. Selain itu, pembangkit listrik ini tidak bergantung pada perubahan cuaca, seperti yang terjadi pada pembangkit listrik tegnaga angin atau tenaga surya. Untuk mendapatkan energi listrik yang maksimal, maka perlu diperbanyak jumlah piezoelektrik dan jumlah langkah kaki manusianya. Sehingga, tempat yang paling baik untuk dipasang lantai pembangkit listrik menggunakan piezoelektrik ini adalah tempat yang banyak dikunjungi orang atau ruang publik.

Penelitian ini dapat dikembangkan pada beberapa wilayah. Desain lantai yang lebih optimal dengan piezoelektrik yang lebih banyak dapat menjadi pengembangan penilitian ini. Selain itu, pengaturan pengisian baterai juga dapat menjadi pengembangan penelitian. Terakhir, lantai pembangkit listrik ini dapat dikombinasikan dengan pembangkit listrik yang lain menjadi pembangkit listrik tenaga hibrid. 


\section{UCAPAN TERIMAKASIH}

Penulis mengucapkan terima kasih kepada Sekolah Tinggi Teknik - PLN yang telah memberi dukungan pelaksanaan penelitian ini.

\section{DAFTAR PUSTAKA}

[1] L. H. Fang, S. . I. S. Hassan, B. A. R. Rozemizi dan M. F. Abd Malek. (2015). "A STUDY OF VIBRATION ENERGY HARVESTER," ARPN Journal of Engineering and Applied Sciences, p. 1.

[2] E. Yulia, E. P. Putra, E. Ekawati dan Nugraha. (2016) "Polisi Tidur Piezoelektrik Sebagai Pembangkit Listrik dengan Memanfaatkan Energi Mekanik Kendaraan Bermotor," Jurnal Otomasi Kontrol dan Instrumentasi Institut Teknologi Bandung, p. 1.

[3] R. Maulana. (2016). "Pemanfaatan Sensor Piezoelektrik Sebagai Penghasil Sumber Energi Pada Sepatu," Teknik Elektro Universitas Muhammadiyah Surakarta, Surakarta.

[4] X. Zhu. (2010). "Piezoelectric Ceramics Materials: Processing, Properties, Characterization, and Applications," dalam Piezoelectric Ceramics Materials: Processing, Properties, Characterization, and Applications, Nanjing, Nova Science Publishers, p. 1.

[5] S. R. Moheiman dan A. J. Fleming. (2006). Piezoelectric Transducers for Vibration Control and Damping, London: Springer-Verlag.

[6] G. Gautschi. (2002). Piezoelectric Sensorics: Force, Strain, Pressure, Acceleration and Acoustic Emission Sensors, Materials and Amplifiers, Berlin: Springer.

[7] M. H. M. Radzi dan K. S. Leong. (2015). "Investigation of The Piezoelectric Charge Coefficient $\mathrm{d} 33$ of Thick-Film Piezoelectric Ceramics By Varying Poling and Repoling Conditions," dalam INTERNATIONAL CONFERENCE ON MATHEMATICS, ENGINEERING AND INDUSTRIAL APPLICATIONS 2014, George Town.

[8] V. R. Ghatage dan P. S. G. Kolgiri. (2016) "Design and Development of PZT Material as Energy Harvester Which Converts Vibration Energy into Electrical Energy," International Education \& Research Journal, vol. 2, no. 1, p. 1.

[9] P. Arun V dan D. Mehta. (2013) "Eco-Friendly Electricity Generator Using Scintillating Piezo," Int. Journal of Engineering Research and Applications, vol. 3, no. 5, p. 479.

[10] M. Zelisko dan K. Anderson. (2018). "Hands-on Activity: Building a Piezoelectric Generator," National Science Foundation GK-12 and Research Experience for Teachers (RET) Programs, University of Houston. [Online]. Available: https://www.teachengineering.org/activities/view/uoh_piezo_lesson01_activity1. [Diakses 3 Januari 2019].

[11] Z. Amelia.( 2017) “Tempo.co," Tempo, 7 November 2017. [Online]. Available: https://metro.tempo.co/read/1031550/tanah-abang-ruwet-tiap-hari-110-ribu-penumpangkereta-yang-turun/full\&view=ok. [Diakses 0801 2019]. 